\title{
SOCIODEMOGRAPHIC FACTORS ASSOCIATED WITH UNFAVORABLE TRADITION AMONG POST PARTUM WOMEN IN BANGKA TENGAH, BANGKA-BELITUNG
}

\author{
Neng Ayu Rosita \\ School of Health Polytechnics, Ministry of Health Pangkalpinang
}

\begin{abstract}
Background: Dietary rules and regulations may govern particular phases of the human life cycle and may be associated with special events such as menstrual period, pregnancy, childbirth, lactation, and - in traditional societies preparation for the hunt, battle, wedding, funeral, etc. Food taboos and restrictions are most commonly practised in relation to pregnancy. Pregnancy in various cultures is attended by many food taboos, beliefs, and restrictions, which are often influenced by traditional notions passed on from one generation to another. This study aimed to determine the association between maternal education and unfavourable traditional food restriction among pregnant women in Buton tribe, Bangka-Belitung.
\end{abstract}

Subjects and Method: This was a quantitative and qualitative study conducted in Buton tribe, Bangka Tengah, Bangka-Belitung. A total of 65post partum women aged $\geq 20$ years were selected for this study. The dependent variable was traditional food taboo and restriction in the post partum period. The independent variables were age, education, and parity. Qualitative data were collected by indepth interview, focus group discussion, and observation. The quantitative data were collected by questionnaire and analyzed by chi-square test.

Results: Of the 65 post partum women under study, 62 (95\%) aged $\geq 20$ years, $53(82 \%)$ had low education level, 49 (75\%) were multiparous, and $55(87 \%)$ practiced traditional tribal food restriction. Bivariate analysis showed a positive association between low education level and traditional tribal food restriction practice. Some of the traditional tribal practice were detrimental to maternal and child health.

Conclusion: Low education level is associated with traditional tribal food restriction practice. Some of the traditional tribal practices were detrimental to maternal and child health.

Keywords: traditional, food taboo, education, parity, post partum women.

\section{Correspondence:}

Neng Ayu Rosita. School of Health Polytechnics, Ministry of Health Pangkalpinang, Bangka-Belitung. Email: n.ayurosita@gmail.com.Mobile: o81214161417. 